\title{
17 "RHODES MUST FALL" - AN ALTERNATIVE APPROACH TO STATUES IN THE SOUTH AFRICAN PUBLIC SPHERE
}

\section{Georgia Alida du Plessis ${ }^{1}$}

\section{INTRODUCTION}

Higher education students of South Africa have recently revived anti-colonial and black consciousness rhetoric with requests for the removal of the Rhodes Statue at the University of Cape Town (UCT) Upper Campus. ${ }^{2}$ The Black Consciousness Movement (BCM) swept across South Africa in the 1970s following the Sharpeville massacre in 1960. BCM organisations helped to educate and organise Black resistance, especially amongst the youth. The BCM urged a defiant rejection of apartheid, saw the rise of the South African Student Organisation (SASO - today called SASCO) as well as the organisation of trade unions. The BCM is synonymous with its founder, Steve Biko - one of the icons of the apartheid struggle. He instilled courage among the masses to fight an unjust system under the banner of Black Consciousness. The BCM meant a new framework of student thinking and flowed from Biko's resentment of the influence of white thought on determining an African's future. Biko then began a search for self-identity and hoped to build up the pride of Black culture. ${ }^{3} \mathrm{He}$ stated that real integration was only possible when once "the various groups within a given community have asserted themselves to the point that mutual respect has to be shown." He further argued, "Each group must be able to attain its style of existence without encroaching on or being thwarted by another ... From this it becomes clear that as long as blacks are suffering from an inferiority complex - a result of 300 years of deliberate oppression, denigration and derision - they will be useless as co-architects of a normal society where man is nothing else but man for his own sake ... Hence what is necessary as a prelude to anything else that may come is a very strong grass-roots build-up of black consciousness." ${ }^{4}$

1 Research fellow in Public Law at the University of the Free State, South Africa.

2 This re-emergence of a Black Consciousness Movement is proclaimed in the media. Leithead A. 2015. "Why South Africa's born-free generation is not happy". Online at: http://www.bbc.com/news/world-africa-34570761. The "rainbow nation" that Nelson Mandela spoke about is being seen as a failed project by many young, particularly black, South Africans and they are demanding more change than South Africa has given them the past 21 years.

3 South African History Online. Online at: http://www.sahistory.org.za/article/ introduction-black-consciousness-movement

4 Biko S. 1987. I Write what I Like. Oxford: Heinemann Educational, Cox and Wyman Ltd, 21. 
It was mostly black South African youths who are part of the "born free generation" 5 who started the "Rhodes Must Fall" (RMF) campaign, which also extended to Oxford University in the United Kingdom. ${ }^{6}$ At UCT, the scenes that erupted around the Rhodes statue ended with the statue being hoisted by crane onto a truck surrounded by students cheering its banishment. ${ }^{7}$ These students were mostly deeply dissatisfied with the remaining presence of colonial and apartheid symbols and religion within the public sphere of South Africa. The student leaders of RMF stated that the campaign was not directed against a particular historical individual but rather the symbols of institutional colonialism beyond democracy. ${ }^{8}$ It was also held that the campaign was not about the denial of a particular history but that the statue continued to exercise power over the present. ${ }^{9}$ Religious symbols and some statues are closely connected to South Africa's apartheid past and stand for white supremacy, racism, imperialism and the oppression of black Africans. As stated by Duane Jethro, the controversies surrounding the persistence of apartheid and colonial symbols demonstrate the contemporary role of established cultural heritage forms in mediating complex histories and belonging in post-apartheid South Africa. ${ }^{10}$

In light of a youth disillusioned and angry about the dreams of a "rainbow nation", 11 a dysfunctional government and remaining legacies of apartheid and colonialism (not only in economic circumstances but also in statues, art work, public displays and religion), how is the issue of heritage protection to be dealt

5 The "born free generation" in South Africa is the first generation of those South Africans who were born after the end of apartheid in 1994. At national level, South African born frees do not possess uniform views on the psychological, political and economic aspects of democracy. They never lived through apartheid and therefore their experience thereof widely differs along lines of race and class. Deep and pervasive racial cleavages in the psychological, political and economic attitudes of this generation remain as well as tremendous diversity in their lived experiences. Norgaard S. 2015. "Rainbow Junction: South Africa's Born Free Generation and the Future of Democracy". Online at: http://cddrl.fsi.stanford. edu/sites/default/files/stefannorgaard_finalcddrlthesis_0.pdf, iii. In their search for identity, the "born free" tag might do more to obscure than reveal political identity. The "born free" tag is also contested because many still feel that they are not free. Norgaard, "Rainbow Junction", 4.

6 See, for example, Elgot J. 2016. “'Take it down!': Rhodes Must Fall campaign marches through Oxford". Online at: http://www.theguardian.com/education/2016/mar/09/ take-it-down-rhodes-must-fall-campaign-marches-through-oxford

7 Kros C. 2015. "Rhodes Must Fall: archives and counter-archives", Critical Arts 29(1):52.

8 Kros, "Rhodes Must Fall", 151.

9 Kros, "Rhodes Must Fall", 152.

10 Jethro DH. 2015. Aesthetics of Power: Heritage Formation and the Senses in PostApartheid South Africa, PhD Diss, University of Utrecht, 2.

11 The concept of a "rainbow nation" was at the time of the end of apartheid a necessary invention as the post-apartheid state tried to mobilise its own social cohesion. The Constitution of the Republic of South Africa provided (and still provides) an important set of inclusive values at a time when suspicion still reigned between different racial groups in the mid-nineteen nineties. Jethro, Aesthetics of Power, 14-15 \& 17. 
with? Can the removal of such heritage be justified by the negative historic connotations of these statues and monuments? How can heritage be protected in a manner that is in line with human dignity, equality and freedom - the cornerstones of the South African Constitution? Although the Constitution of the Republic of South Africa, 1996, promotes human dignity, equality, freedom and diversity, it does not clearly state when public symbols such as statues and monuments infringe these values. Also, although the National Heritage Resources Act (NHRA) 25 of 1999 provides for the legal removal of undesirable monuments by way of obtaining a permit, it does not provide guidelines as to when a monument or statue is undesirable, discriminating or contrary to human dignity.

This chapter seeks to address from a South African Constitutional perspective the manner in which to deal with recent events of "iconoclasm" relating to controversial religious, cultural or historical statues containing and representing negative elements of the history of the South African society. "Iconoclasm" also holds a specific connection with religion (but is not limited to it) in the sense that it was used during the Protestant Reformation (as only one example) as a reaction against the perceived idolatory of the Catholic Church and any iconoclastic act seen as a form of "heresy" against the Catholic Church.

The first part of this chapter investigates the historical narrative that created the controversies around these statues. The second part investigates recent waves of iconoclasm (such as the RMF campaign), the elements imbued therein and the reasons for their occurrence. Third, the South African legal framework and governmental reactions regarding "iconoclasm" are investigated, as well as whether the current South African position provides an adequate way to deal with the emotional and political sentiments surrounding recent iconoclastic acts. Finally, in light of the lack of proper guidelines surrounding such acts, the chapter provides for an alternative way to deal with offensive statues. The alternative method is argued to be in line with human dignity, equality and freedom as provided for in the Constitution of the Republic of South Africa. Two notions developed by Charles Taylor, ${ }^{12}$ namely the "politics of recognition" and a "presumption in favour of equal worth", are presented as a bottomup approach to identity formation. Also, the notion of "deep diversity", as developed by Taylor, is presented as a framework within which these issues should be considered. The parameters of deep diversity and equal worth must enhance and give effect to the notions of human dignity, equality and freedom.

12 Taylor C. 1994. The Politics of Recognition. Multiculturalism: Examining the Politics of Recognition. Princeton: Princeton University Press, 25-73. 


\section{THE HISTORICAL NARRATIVE BEHIND THE CONTROVERSIAL SYMBOLS AND MONUMENTS}

In order to understand the anger surrounding the presence of colonial and apartheid statues as remaining legacies of a discriminating South African past, it is vital to understand the history that these statues and religious symbols represent. Cultural and religious identity in South Africa is defined by its history, as well as attempts to escape from such history. Such an escape is partly manifested in setting up statues that contradict or challenge existing colonial statues ${ }^{13}$ or the mere removal of religious and cultural symbols, $\operatorname{logos}^{14}$ and statues. However, in order to understand these attempts to escape, one has to understand the memory from which escape is sought.

During apartheid, schools in South Africa, as elsewhere, reflected society's political philosophy and goals. ${ }^{15}$ A group of Afrikaner churches proposed an education programme, Christian National Education (CNE), to serve as the core of the school curriculum. ${ }^{16}$ The National Education Policy Act 39 of 1967 at the time, clearly stated that education had to have a Christian character. ${ }^{17}$ With the National Party's reign and the enactment of the Bantu Education Act 47 of 1953, CNE became the official education policy during apartheid. Black schools had inferior facilities, teachers, and textbooks. ${ }^{18}$ By 1989, hundreds of political activists had been murdered, thousands had died in inhumane conditions in mines, native populations no longer had land of their own and tens of thousands were incarcerated, many of them without trial. ${ }^{19}$

Despite the fact that more than twenty years have passed since the end of apartheid and the beginnings of the pursuit of dreams of a rainbow nation, symbols of religious and racial apartheid and religious and cultural colonialism can still be found in the South African public sphere. South African youths, especially the black youth, still claim to be bound by the shackles of apartheid, colonialism and its legacy. Although born after apartheid, this generation claims that they are legally free but still carry the burden of an identity forged by apartheid and live their lives in a country with elements and demographics that remind them of apartheid's continuing legacy. ${ }^{20}$

13 Examples of such monuments are the Blood River Wagon memorial and the Ncome Zulu cultural exhibition in KwaZulu-Natal.

14 Many South African universities recently changed their logos and slogans to remove any religious connotations.

15 South Africa: A country study. Online at: http://www.country-data.com/frd/cs/ zatoc.html

16 South Africa: A country study.

17 Horrell M. 1978. Laws affecting race relations in South Africa: 1948-1976. Johannesburg: South African Institute of Race Relations, 350.

18 Horrell, Laws affecting race relations, 295.

19 Peffer J. 2005. "Censorship and iconoclasm - unsettling monuments", RES: Anthropology and Aesthetics 48:46.

20 Norgaard, "Rainbow Junction", 2. 
Although South Africa transitioned from an apartheid government to a democracy in the early 1990s, the policies have a continued legacy of significant inequality. The burden of many of these inequalities falls on South African youths in terms of education, employment, poverty, and health outcomes. ${ }^{21}$ Approximately $64.5 \%$ of children live in households that fall within the bottom two income quintiles with a per capita income of less than R765.00 per month, and $70.5 \%$ of black African children live in low income households, compared to only $4.4 \%$ of white children. ${ }^{22}$ In 2013 , the youth unemployment rate was $63 \%$ of the youth labour force (3.2 million individuals). ${ }^{23}$

The hopelessness and anger at recurring patterns of injustice and inequality caused by apartheid legacy, and an increasingly incompetent and corrupt South African government, have resulted in a series of events such as the defacing and removal of cultural and religious symbols and slogans from the South African public sphere - especially in institutions of higher education. For students participating in the RMF movements, transformation has not been complete. In their view, they are still trapped in structures of marginalisation, because society is still functioning within the values of colonialism and apartheid. The destruction of images has entailed a process of arguing that what many had been going along with had been a grave mistake. This is also a tough admission to make. ${ }^{24}$ At the same time white South African youth are caught between unwillingly or involuntarily carrying the blame and feelings of guilt for the remaining legacy of apartheid. Some of the white youth are able to understand the anger and frustration of fellow black students, while others view the movement as an act of racism and a threat to their culture and the Afrikaans language. This wave of "iconoclasm", rooted in the mentioned anger and accusations of not being heard, needs closer attention and constitutional deliberation.

\section{WAVES OF ICONOCLASM}

The defacing of statues is not a new occurrence. In the academic world, it is called iconoclasm. In general, iconoclasm is the destruction or alteration of images, objects and art imbued with some kind of symbolic value, and can extend beyond tangible objects. ${ }^{25}$ Since the French Revolution, the breaking of

21 Kriel AJ, Whitehead KA and Richter LM. 2005. "Barriers to Conducting a Community Mobilization Intervention Among Youth in a Rural South African Community", Journal of Community Psychology 33(3):253-259.

22 Lehohla P. 2013. Statistics South Africa. Social profile of vulnerable groups (2002-2012). Report No. 03-19-00 (2002-2012).

23 Oosthuizen M and Cassim A. 2014. "The State of Youth Unemployment in South Africa". Online at: http://www.brookings.edu/blogs/africa-in-focus/ posts/2014/08/15-youth-unemployment-south-africa-oosthuizen

24 Peffer, "Censorship and iconoclasm", 59.

25 Kolrud K and Prusac M. 2014. "Introduction", in Kolrud K and Prusac M (eds). Iconoclasm from Antiquity to Modernity. Aldershot: Ashgate, 1. 


\section{Religion, Hate Speech, Diversity and Equality}

images and destruction of idols have been linked to the rhetoric of revolutionary politics. ${ }^{26}$ Iconoclasm was present from the Byzantine ${ }^{27}$ to the Reformation periods. ${ }^{28}$ Protestant Reformers such as John Calvin encouraged the removal of religious images by invoking the prohibition of idolatry. The removal of an emperor's visual presence was a means of controlling or depressing debate. ${ }^{29}$ In antiquity images of the emperor were destroyed as an act and a means of wiping out his memory, and one may say that the practice has continued and continue to this day. "Iconoclasm depends on the power of the image, in as much as a neglected image, which is no longer the object of either worship or hatred, remains an unlikely target." ${ }^{31}$ More recently, on a campus in Texas the words "black lives matter" were spray-painted over three statues of Confederate leaders. ${ }^{32}$ The toppling of the statue of Saddam Hussein is another more recent example. $^{33}$

Iconoclasm is not new to South Africa. Following the tumultuous years during the transfer to a democracy, there were several iconoclastic reactions. Initial erasure of the colonial heritage enacted as a form of decolonisation was later followed by a more inclusive redress - such as adding new moments or layers of suppressed history to existing places of commemoration. ${ }^{34}$ Statues were removed, art was removed from parliament and original African names were reinstated. Iconoclasm has again reached epidemic proportions between 2014 and 2016. Besides the Rhodes statue at UCT, others statues that were subject to iconoclasm included the Queen Victoria statue in Port Elizabeth and the CR Swart statue at the University of the Free State campus (2016). Since RMF, there have been about twenty other similar incidents in South Africa. ${ }^{35}$

Besides the anger and disappointment of the youth with the continuing legacy of apartheid and a dysfunctional government, these statues also represent a continuing legacy that assists in continuing frameworks of inequality. As

26 Clay R. 2012. "Re-Making French Revolutionary Iconoclasm", Perspective 1:181-186.

27 Also see the chapter on "Islam, Judeo-Christianity and Byzantine Iconoclasm", in Patricia Crone. Religion, Law and Political Thought in the Near East, c.600-c.1100. Aldershot: Ashgate Variorum.

28 Kolrud and Prusac, "Introduction", 4.

29 Kolrud and Prusac, "Introduction", 6.

30 Kolrud and Prusac, "Introduction", 5-6.

31 Kolrud and Prusac, "Introduction", 6.

32 Tani M. 2015. "Confederate Statues at University of Texas spray-painted with 'black lives matter'." Online at: http://uk.businessinsider.com/confederatestatues-defaced-at-ut-austin-20156?r=US\&IR=T

33 Axelfod J. 2013. “A decade after Saddam Hussein's statue falls: A tale of two memories." Online at: http://www.cbsnews.com/news/a-decade-after-saddamhusseins-statue-falls-a-tale-of-two-memories/

34 Bakker KA and Müller L. 2010. "Intangible Heritage and Community Identity in Post-Apartheid South Africa", Museum International 62(1-2):48.

35 For a list, see http://www.theheritageportal.co.za/thread/vandalisation-statuessouth-africa 
described by John Peffer, these are images ${ }^{36}$ of pain and torture, murder, labour that lobotomise and bury its shattered men. ${ }^{37}$ The psychological analyses of iconoclasm and the relationship between statues and the living beings that occupy the space these statues occupy remain complicated. Some are of the opinion that monuments are capable of radiating an impression of "supernatural omnipresence" and the bodily experience of constructed space. There is a vivid intercommunication between monument and spectator. ${ }^{38}$ During the RMF protests one student stated that the flinging of human faeces at the statue was so that the statue "feels" ashamed the way he (the student) feels ashamed that these faeces are in his living environment. The attempt was to "desanctify" the statue $^{39}$ and to make it human..$^{40}$ Irrespective of the psychological reasons for iconoclasm, offensive statues influence human dignity, identity formation and constitutional rights. Monuments and statues are literally markers of conceptual spaces and responsible for mapping a landscape. They serve the present and are designed to preserve memory for the sake of future generations. Therefore, the absence of some monuments, or the representation of only one history, can represent history in a conjured fashion ${ }^{41}$ and affect constitutional rights.

Amidst the human rights implications of the effect of such statues on the human dignity of people and their perception of being equal and free in a society, what is the most constitutional manner in which to deal with obscure statues within public spaces? Not only do these statues represent parts of history - albeit very negative parts - their psychological and consequent effects on the human rights of those who are confronted with them daily are of utmost importance. Within public spaces, a balance is to be struck between preserving history and heritage, remaining inclusive of all religions and cultures within South Africa and maintaining an environment representative of equality. This immediately poses the following question - how to balance these factors in the most constitutional manner and in line with the underlying values of the Bill of Rights, such as human dignity, equality and freedom. Do these statues and logos achieve equality, human dignity and freedom? Will the defacing or removal of statues achieve these rights? Does the apartheid and colonial history have a place in the present? In order to answer these questions, the legal framework within which they should be answered is clarified.

36 These images are not limited to statues but also include spaces such as the Voortrekker Monument.

37 Peffer, "Censorship and iconoclasm", 46.

38 Kros, "Rhodes Must Fall", 153.

39 Kros, "Rhodes Must Fall", 154.

40 Kros, "Rhodes Must Fall", 155.

41 Marschall S. 2003. "Setting up a dialogue: monuments as a means of 'writing back"', Historia 48(1):317. 


\section{THE CONSTITUTION, LAW AND GOVERNMENT CONCERNING ICONOCLASM}

The Preamble of the Constitution of the Republic of South Africa, 1996 states:

We, the people of South Africa,

Recognise the injustices of our past;

Honour those who suffered for justice and freedom in our land;

Respect those who have worked to build and develop our country; and

Believe that South Africa belongs to all who live in it, united in our diversity.

When applying this foundational paragraph to iconoclasm in a complicated country such as South Africa, several questions emerge. How can the injustices of our past be recognised? Can it be done by eliminating all signs thereof? By keeping all signs thereof and remembering the injustices they caused? By recognising and acknowledging the signs of injustice but recreating them to reveal their bias, for example the insertion of a commemorative site, such as the Blood River museum, to provide a more balanced approach to history ${ }^{42}$

The National Heritage Resources Act 25 of 1999 (NHRA) provides limited answers. Public monuments and memorials are defined as "erected on land belonging to any branch of government or any organisation funded or established in terms of legislation or which is paid for by government funds". Section 37 of NHRA states that public monuments and memorials must be protected in the same manner as places entered in a heritage register. This means that no person may destroy, damage, deface or remove such a monument without a permit issued by the heritage resources authority responsible for the protection of such a site. ${ }^{43}$ Therefore, the removal or defacing of statues is possible, but it should follow a specific procedure and can only be done with a permit issued by the appropriate authorities. The NHRA does not give any guidelines as to when such a permit is to be given or not.

The African National Congress (ANC) government has tried to hold a rather rational position in these instances - a position that does not account for the urgency, anger and feelings of indignation of the South African youth. Government holds that heritage sites and monuments have cultural significance and value because of their importance to a community in revealing a pattern of South Africa's history. It demonstrates a particular aspect of a particular time. Government promotes a transformative agenda while accepting that the past cannot be completely wiped away. For this reason, and as part of transformation, the diverse voices of all citizens of South Africa must be allowed to express themselves. A national policy of reconciliation, nation-building and social cohesion is promoted by the government. ${ }^{44}$ Therefore, the government's

42 Bakker and Müller, "Intangible Heritage", 48.

43 National Heritage Resources Act, section 27(18).

44 Online at: http://www.gov.za/speeches/minister-arts-culture-mr-nathi-mthethwadefacing-and-or-violent-removal-colonial-statues-8 
approach is largely conservative and aimed at racial reconciliation. ${ }^{45}$ This policy followed the example of Afrikaner policy during apartheid towards old, offensive and controversial British monuments, which was aimed at establishing a constructive dialogue between older and new monuments. ${ }^{46}$ In an attempt to set up dialogue, many post-apartheid monuments have been placed near existing older monuments to seek confrontation with the colonial and apartheid legacy. ${ }^{47}$

Clearly, and based on recent events of iconoclasm, the government's approach has not appealed to the anger and frustration of large sections of South Africa's youth. Furthermore, the South African laws, such as the NHRA, are rather vague in establishing the conditions when a permit for removal will be granted and under which conditions. Who decides what stays and what goes and under what criteria?

Although the South African Constitution provides that all laws and policies should enhance the values and rights of human dignity, equality and freedom, non-racialism and non-sexism, ${ }^{48}$ it is not clear how these values will be interpreted and balanced in cases of iconoclasm. Black South African youths may claim that the existing colonial and apartheid statues infringe their right to equality, human dignity and freedom. They may claim that they cannot be free and equal in the presence of these statues and that it causes them to experience unfair discrimination. Section 9 of the Constitution clearly states that, if there is discrimination, it has to be shown that it is unfair discrimination before being declared unconstitutional. When one of the 17 expressly mentioned grounds is discriminated against in Section 9 (including race), the presumption is that such discrimination will be unfair, unless the contrary can be proven. ${ }^{49}$ If the presence of a statue leads to racial discrimination, it is presumed that the presence of such a statue is discriminating and contrary to equality, unless the contrary can be proven. The constitutional guarantee of equality must be interpreted contextually, entailing a historical understanding of South

45 Marschall S. 2003. "Setting up a dialogue: monuments as a means of 'writing back"”, Historia 48(1):317. Also see Duane Jethro D. 2014. “Cecil Rhodes, Heritage Formation and Contemporary Popular Culture". Online at: http://historymatters. co.za/content/cecil-rhodes-heritage-formation-and-contemporary-popularculture-duane-jethro

46 Marschall, "Setting up a dialogue: monuments as a means of 'writing back"', 318. Here "dialogue" means that the political, social or religious history of one statue challenges or confronts the political, social or religious history of another sharing the same public space. Such "dialogue" therefore refers to the historical narrative behind the statues.

47 Marschall, "Setting up a dialogue", 318.

48 Sections 1, 9 and 10 of the Constitution.

49 See section 9(5) of the Constitution. In section 9, the grounds for unfair discrimination are race, gender, sex, pregnancy, marital status, ethnic or social origin, colour, sexual orientation, age, disability, religion, conscience, belief, culture, language and birth. 


\section{Religion, Hate Speech, Diversity and Equality}

Africa's past and South Africa's future. ${ }^{50}$ In Pretoria City Council v. Walker ${ }^{51}$ the Constitutional Court of South Africa stated that when determining equality, it has to be assessed against the background of the preceding paragraphs of section 9 and the constitutional and historical context of the developments in South Africa. ${ }^{52}$ The presence of discriminatory statues and whether it leads to the infringement of equality should take into account the history of South Africa and how such history enlarges sensitivities to anything that mirrors it including statues. It should also be determined whether the presence of a statue is conducive for remedying remaining patterns of disadvantage and achieve substantive equality.

A distinction has to be made between formal and substantive equality. South Africa follows an approach that adheres to substantive equality. Law professor Sandra Fredman (University of Oxford, but born in South Africa) states that recent decades show growing acceptance of the limits of formal equality with its focus on the abstract individual, as this has "failed to address deeply entrenched patterns of social disadvantage". This also means that equality requires more than restraint from the state. It requires active transformation to change entrenched patterns of disadvantage. Fredman further states that the abstract individual of formal equality is a myth. ${ }^{53}$ As economist and philosopher Amartya Sen argues: “Equal consideration for all may demand very unequal treatment in favour of the disadvantaged. The demands of substantive equality can be particularly exacting and complex when there is a good deal of antecedent inequality to counter." 54

Equality jurisprudence must thus be truly "transformative" and not merely "inclusionary". ${ }^{55}$ It will not be sufficient to simply remove discriminatory statues, laws or practices but, rather, as stated in Sections $7^{56}$ and 9, there are categories of disadvantaged persons who should be advantaged (even by way of differentiation and fair discrimination) and the state should actively promote this. Substantive equality may thus require active removal of statues by the state in order to eradicate remaining discrimination, rather than a negative or passive approach of non-involvement by the state.

50 Currie I and De Waal J. 2005. The Bill of Rights Handbook, 5th ed. Cape Town: Juta, 231. 511998 (2) SA 363 (CC) (1998 (3) BCLR 257).

52 Pretoria City Council v. Walker 1998 (2) SA 363 (CC) (1998 (3) BCLR 257): para graph 26.

53 Fredman S. 2005. "Providing Equality: Substantive equality and the positive duty to provide", South African Journal of Human Rights 21:165.

54 Fredman, "Providing Equality", 166.

55 Albertyn C. 2007. "Substantive Equality and Transformation in South Africa", South African Journal of Human Rights 23:254. See also Fredman, "Providing Equality", 167.

56 Section 7 states the following: "(1) This Bill of Rights is a cornerstone of democracy in South Africa. It enshrines the rights of all people in our country and affirms the democratic values of human dignity, equality and freedom. (2) The state must respect, protect, promote and fulfil the rights in the Bill of Rights ..." 
Does this mean that, because of past injustices, old colonial and apartheid statues can be removed and merely replaced by new ones advancing the interests of previously disadvantaged racial groups? Has the government's reconciliatory approach towards monuments in public spaces been transformative or merely inclusive? Has the government been radical enough to address and transform persisting patterns and images of injustice in public spaces? Although the South African Constitution provides for a general normative framework on how to deal with obscure statues in the public sphere when it amounts to equality claims and other human rights issues, it is unsure what the outcome would be for each and every monument or statue. The outcome will probably be determined on a case-by-case basis, with special emphasis on remedying past injustices and transforming society. Within the framework of the constitutional analysis applicable to each case concerning an offensive statue, this chapter aims to introduce a number of important factors that are fundamental to consider during this analysis. Hence, subject to the right to equality and the right to human dignity, this chapter wants to establish a new framework for participation and social inclusion concerning statues in the public sphere. These considerations wish, in the manner proposed by law professor Catherine Albertyn, to facilitate or establish new, non-hierarchical, normative frameworks of participation and social inclusion that are transformative. ${ }^{57}$ Neither the approach of removing statues, nor the mere addition of state determined cultural artefacts to the public sphere will serve as the most constitutional approach in upholding equality, human dignity and freedom. Mere removal represents an act of censorship and mere additions by the state a lack of deep diversity and transformation. What is needed is a bottom-up approach seeking initiatives from civil society rather than a top-down approach where culture and national identity are determined by the state.

\section{CENSORSHIP AND ICONOCLASM}

Although the removal of a statue or monument will depend on and ultimately be determined in light of the Constitution of the Republic of South Africa, 1996, one should be weary of the potential effects of iconoclasm and the complete removal of statues. Although the effects on the human dignity of previously disadvantaged groups might be great, the possibility should be considered that the removal of a statue might have an even greater disadvantageous effect on the human dignity of previously disadvantaged groups.

This possible disadvantageous effect refers to the relationship between iconoclasm and censorship. It is possible that actions of defacing or removal may actually silence and ignore the injustices of the past, rather than dealing with it. It is the same as saying that a subject should not be talked about because it is too painful. Iconoclasm can prohibit a public sphere of active debate

57 Albertyn, "Substantive Equality", 260. 


\section{Religion, Hate Speech, Diversity and Equality}

because the hurts of the past are removed visually, but not emotionally. By sterilising and silencing the public sphere and history, we are only silencing the pain $^{58}$ and preventing dialogue aimed at reconciliation. The possibility exists that completely removing the image creates an emptiness - this is a primary form of iconoclasm.

On the other hand, if a statue is maintained, what is to be done about the politics of memory $?^{59}$ Whose memory is to be attached to a statue and what should it say? Because memory is not an undeviating concept and is highly political, ideological and subjective, it is argued that an approach most suitable under a regime of human dignity, equality and freedom is a highly inclusive approach - one that promotes and gives voice to all the memories attached to a statue. Even if one memory is not preserved, but the debate surrounding the statue is ongoing, it is more important that the diverse voices are recognised and history and political issues constantly reviewed. This is in line with the approach following a politics of recognition proposed below. It is suggested that it might be that between all the different memories about a single event, lies the actual events. Yet, in our pursuit to establish what exactly happened (if that is even possible) all different memories should be honoured. It might seem an impossible task, but democracy is not supposed to be easy and will take hard work, effort and sacrifice. This is a form of the secondary type of iconoclasm promoted in this chapter.

A secondary type of iconoclasm is a way of using the iconoclastic gesture to attack censorship, address the hurt attached to the monument and its imposition on human dignity, without removing or damaging the obscure object. John Peffer suggests that through a secondary type of iconoclasm, memory can also be countered as opposed to officially and unofficially sanitised versions of history. ${ }^{60}$ Secondary iconoclasm addresses the reasons why the statue is offensive, rather than ignoring that the hurt is present. One example of a secondary form of iconoclasm (in the form of a protest action) is South African artist Tracey Rose's attempt to unravel doilies (made by the "coloured"61 community outside Oudtshoorn) at the Klein Karoo National Arts Festival in 1998. She wound the threads around a police monument of an

58 Peffer, "Censorship and iconoclasm", 45.

59 See, for example, the politics of memory concerning the Second World War Ther P. 2006. "The burden of history and the trap of memory." Online at: http:// www.eurozine.com/the-burden-of-history-and-the-trap-of-memory/. The issues pertaining to memory and its service to justice can clearly be seen in the South African history and methods of dealing with painful memory - for example, the Truth and Reconciliation Commission (TRC). Here it is important to understand that there are dangers to forgetting but also dangers to the manipulation of memory and presenting it as the "truth". See Duvenage P. "The Politics of Memory and Forgetting After Auschwitz and Apartheid". Online at: http://mobile.wiredspace. wits.ac.za/bitstream/handle/10539/7767/HWS-106.pdf?sequence=1

60 Peffer, "Censorship and iconoclasm", 222.

61 Usually, in South Africa, persons of mixed race origin refer to themselves as coloured. 
officer and his dog. Several white male officers demanded that she cease the work until one of them finally cut the doily threads with a knife. The act of unravelling constituted an effort to lay open the past and make visible acts of oppression under apartheid..$^{62}$ When she was asked why she used doilies, she stated that when she grew up women were shut up in a women's knitting circle from age sixteen and older, and doilies were the trophy of female worth. Doilies represented repressed and oppressed emotions and self-censorship. Mixed race females in Oudtshoorn during apartheid were seen as sex objects used by men. If you were "coloured" you were the product of some kind of "illicit sex". Wrapping a monument of the police in doilies was meant as an unravelling of the history behind the public image. Rose saw her performance not as destruction, but as re-creation and reformation of the relationship between mixed race women and white men. ${ }^{63}$ Other similar acts included for example Loslyf's publication of semi-naked women in front of the Voortrekker monument - ridiculing Afrikaner pride. ${ }^{64}$ These secondary means of iconoclasm deprive the image of its power and diminish its political power in the same way as primary iconoclasm does. ${ }^{65}$ The secondary approach to iconoclasm is revolutionary in that it does not bury oppressive images in the waste heap of history, but rather keeps them in play. ${ }^{66}$ However, these monuments are not kept in play in a static manner. There are many ways to unsettle a monument by revealing a new semantic wealth by opening up previously occluded meaning. The vision can be pulled apart and new possibilities found. ${ }^{67}$

The secondary form of iconoclasm becomes a form of dialogue and debate - a proposal and a reply. When considering the equality considerations explained above, it should also be taken into account that the removal of statues might silence the injustices of the past and amount to censorship, which in turn can cause greater harm to human dignity and equality. The South African government has practised such a secondary form of iconoclasm by inserting commemorative cites within existing sites, representing and highlighting the layers, intricacies and development of oppression. An early example is the Ncome Monument, created in 2000. It corrects the one-sided iconographic representation of the "Battle of Blood (Ncome) River" and intends oppositional content. It does represent Voortrekker artefacts and history but also represents and transforms this history. ${ }^{68}$ However, these changes were mostly done by the state, resulting in a hegemonic, dominant voice about culture, and

62 Peffer, "Censorship and iconoclasm", 55.

63 Peffer, "Censorship and iconoclasm", 56.

64 Peffer, "Censorship and iconoclasm", 56. Loslyf used to be an extremely controversial Afrikaans pornographic magazine. It represented everything the Nationalist apartheid government did not stand for and challenged the ideologies of Afrikaner Nationalism. The word "Loslyf" is a slang Afrikaans word that depicts a sense of freedom pertaining to one's body.

65 Peffer, "Censorship and iconoclasm - unsettling monuments", 58.

66 Peffer, "Censorship and iconoclasm - unsettling monuments", 59-60.

67 Peffer, "Censorship and iconoclasm - unsettling monuments", 60.

68 Bakker and Möller, "Intangible Heritage", 48. 


\section{Religion, Hate Speech, Diversity and Equality}

silencing many a dissonant and smaller voice ${ }^{69}$ - in other words, an indirect imperial dominance by the state of what the public space should look like. The imposition of a cultural identity by the state, whether by adding or removing statues, supports static conceptions of history, while modification from the local community realises democracy at local level and promotes a bottom-up approach. ${ }^{70}$ Therefore, a top-down state imposed cultural identity countering these statues will merely censor dissenting voices and deny groups of persons the opportunity to create their own identity from the bottom-up. A bottomup approach avoids a single narrative of cultural identity. It will promote democracy at the local level and notions of deep cultural diversity and equal worth, as advocated by Charles Taylor.

\section{DEEP DIVERSITY, THE POLITICS OF RECOGNITION AND EQUAL WORTH VS A SINGLE NARRATIVE}

If the state is the main purveyor of heritage and a hegemonic voice in the production of cultural heritage, then fluid and meaningful dialogue between different cultures becomes impossible and minority and diverse cultures are drowned. This amounts to a convergence of cultures and a lack of recognition of diversity. The state has mostly emphasised the use of static monuments while avoiding complex narratives. ${ }^{71}$ Although the state should launch initiatives and promote commemoration (and various versions of commemoration) and dialogue through the medium of statues, this should not prevent the freedom of expression of local communities, but rather encourage the creation of cultural identity from the real centre of the narratives - the communities themselves. On various microlevels the struggle should be commemorated from the centre narratives. ${ }^{72}$ This adds to authentic dialogue with existing statues and monuments of colonialism and apartheid. Failure to engage the dialogue and expression of the community will result in general apathy and disengagement by the younger generation. ${ }^{73}$ Such fluid and open-ended heritage conservation does not place the emphasis on consensus, but rather so that differences and complexity may be continually explored. ${ }^{74}$

Narrow definitions of history and culture should be rejected ${ }^{75}$ and the complexities that involve South Africa's history should be represented in statues - not merely the constructed identity of the government. The national identity constructed by the state can be seen in commemorations like the

69 Bakker and Möller, "Intangible Heritage", 49.

70 Peffer, "Censorship and iconoclasm", 59.

71 Bakker and Möller, "Intangible Heritage", 50.

72 Bakker and Möller, "Intangible Heritage", 50.

73 Bakker and Möller, "Intangible Heritage", 50.

74 Bakker and Möller, "Intangible Heritage", 54.

75 Wright JP. 2010. Memory, Monuments and the South African National Imaginary: Constitution Hill and the Fiction of Ivan Vladislavic, MA Thesis, University of KwaZulu-Natal, 6. 
Apartheid Museum. This museum creates a static and simplified history, but not a dialogue entailing disagreement. It rather represents consensus and the inevitability of the current dispensation with its unquestioned legitimacy. ${ }^{76}$ The Apartheid Museum speaks a constant monologue that drowns out other voices. ${ }^{77}$ It presumes a national imagery and consensus about South Africa without considering the fact that people have different notions of the past and that their present identities are difficult to include in a unitary nation. It does not take account of disagreement and diversity. ${ }^{78}$ Such a unifying approach to cultural identity is irrelevant to black youth amidst a collective identity crisis in post-apartheid South Africa. Consequently, they "hark back" to the past (decolonisation of statues) with amplified intensity ${ }^{79}$ - as recently seen in the "Rhodes Must Fall" campaign.

What is called for is an opening-up in thinking about South African heritage and apartheid. South Africa has, up to now, been written about as a closed separate space. It should not be viewed as a space separate from other decolonised countries where identity and culture are merely defined by government in light of victimhood. South African culture is more than the liberation narrative and fights over racial supremacy and racial victimhood as a determinant of identity - although this is a very important part of it. Culture and identity in South Africa have always been more fluid. Culture and identity were first restricted by apartheid and are now constrained by the oversimplified discourse of rainbow nationalism, racial victimhood and racial supremacy. ${ }^{80}$ Instead of merely removing old statues and adding new ones representative only of a simplistic state-imposed identity - which would undermining the richness of South African culture - a notion of deep diversity and equal worth would enable all groups of society to create a living and vibrant dialogue by way of public representations of statues and monuments. In light of the concept of deep diversity and equal worth, these public spaces should not only represent colonial style statues and monuments, but also commemoration inherent in the represented culture itself.

Merely adding a statue to the already existing one in order to stimulate dialogue, creates a new identity, philosophy and understanding of the public sphere - but one that is currently solely determined by the state. A deeply diverse South African heritage should be presented in the public sphere, and one that is constructed from the bottom-up and not only by the state or via a state-imposed identity. These styles should not merely be similar to those of existing colonial and apartheid statues, but should be authentic to its culture. These monuments should "write back" but not only in the language of the

76 Wright, Memory, Monuments, 70.

77 Wright, Memory, Monuments, 71.

78 Wright, Memory, Monuments, 65.

79 Wright, Memory, Monuments, 66.

80 Wright, Memory, Monuments, 5. 


\section{Religion, Hate Speech, Diversity and Equality}

coloniser by way of statues of new heroes cast in bronze. ${ }^{81}$ This can be part of it, but should also be a celebration of the aspects inherent in the culture itself. Such an approach is rooted in self-reflection and blocked from falling into a new kind of censorship. ${ }^{82}$

There are two suggested ways of achieving such a public space: (1) by secondary iconoclasm as explained above; (2) by a grass-roots approach taking account of deep diversity and equal worth. Since the first one has already been dealt with, I move now to address the second suggestion.

In his important essay, The Politics of Recognition, Canadian philosopher Charles Taylor states that besides the fact that the protection and promotion of plural religions and cultures within the public sphere involve matters of human dignity, equality and freedom, it also concerns what Charles Taylor calls "the politics of recognition". ${ }^{83}$ In the present day, we understand the formation of identity and the self as taking place in a continuing dialogue and struggle with others and then in the public sphere, where a politics of equal recognition has come to play a bigger and bigger role. ${ }^{84}$ However, the modern notion of identity emphasises equality but also that everyone should be recognised for his or her unique identity. ${ }^{85}$ It is argued that our identity is partly shaped by the recognition or absence of recognition of others, and so a person or a group of people can suffer true damage. Misrecognition can inflict harm, be a form of oppression, imprisoning someone in a false, distorted, and reduced mode of being. ${ }^{86}$

Denying any culture or cultural history a part in the public sphere can lead to the misrecognition of that culture and a violation of their human dignity. This can be done by the indiscriminate removal of both statues and monuments because they stem from the pre-1994 period. It could also be caused by a lack of recognising the deeply diverse and complex natures of majority and minority cultures by way of a state-imposed hegemonic identity based on the sole dialogue of racial victimhood and racial superiority. Such recognition should also not be manifested in replicating liberal and colonising methods of commemoration - namely statues. In order to give effect to the recognition of

81 Marschall, "Setting up a dialogue", 321.

82 Peffer, "Censorship and iconoclasm - unsettling monuments", 59

83 Taylor C. 1994. The Politics of Recognition. Multiculturalism: Examining the Politics of Recognition. Princeton: Princeton University Press, 25-73.

84 Taylor, The Politics of Recognition, 37.

85 Taylor, The Politics of Recognition, 38.

86 Taylor, The Politics of Recognition, 25. According to Duane Jethro, the Rhodes Must Fall Movement questioned these exact ideas of tolerance, the recognition of all histories on equal terms and the unquestioned inclusion of all material pasts. Jethro, Aesthetics of Power, 243. 
this diversity, Taylor argues for a "presumption in favour of equal worth". He argues that it is:

... reasonable to suppose that cultures that have provided the horizon of meaning for large numbers of human beings, of diverse characters and temperaments, over a long period of time - that have, in other words, articulated their sense of the good, the whole, the admirable are almost certain to have something that deserves our admiration and respect, even if it is accompanied by much that we have to abhor and reject. ${ }^{87}$ Perhaps one could put it another way: it would take a supreme arrogance to discount this possibility a priori. There is perhaps after all a moral issue here. We only need a sense of our own limited part in the whole human story to accept the presumption. It is only arrogance, or some analogous moral failing, that can deprive us of this. ${ }^{88}$

Although Taylor here talks about the guilt of Western liberal societies in imposing their views of what is worthy on other cultures, ${ }^{89}$ this can be extended to the argument that diverse cultures within South Africa should be seen as having inherent equal worth. It should not be viewed merely from the perspective of the decolonisation and apartheid narrative proposed by government to forge national identity. Although this narrative has influenced various cultures, it is not the only element that defines them. They are equally worthy in their own splendour and richness. Solely because of this they should be commemorated within the public sphere - all of them.

Charles Taylor's concept of "deep diversity" is one that he introduced in an essay, titled "Deep Diversity and the Future of Canada", but it applies equally to South Africa's deeply diverse and complex society. Deep diversity centres on celebrating ethnic, cultural and religious distinctiveness and promotes diversity in deeper layers of identity formation and social relations. ${ }^{90}$ In other words, deep diversity acknowledges and celebrates the fact that the identity and memory of a human being is not only one-dimensional. There are religious, cultural, political, economic and historical factors (amongst others) that influence and create memory and identity. Furthermore, it will be a grave injustice to view such identity-formation from only one ideological perspective that is abstracted from the reality of an individual, a cultural group or a religious group of persons. It includes an ethical account that acknowledges and addresses diversity in multicultural societies, without expecting distinct persons to be abstracted from their own distinctiveness and specification. ${ }^{91}$ The value and importance of the culture is not judged from outside national identity, but also by that which is inherent in the culture. It is more than mere toleration

87 Taylor, The Politics of Recognition, 72-73.

88 Taylor, The Politics of Recognition, 73.

89 Taylor, The Politics of Recognition, 63.

90 Masaeli M. 2013. The Ethics of Deep Diversity in Multicultural Societies - Part I. Online at: http://livebettermagazine.com/article/the-et

91 Masaeli, The Ethics of Deep Diversity - Part I. 


\section{Religion, Hate Speech, Diversity and Equality}

and more than mere acknowledgement of diversity. Rather, it actively engages in the "political recognition of the distinctiveness of different others". It also allows for a more participatory discourse of democratisation and inclusion in multicultural societies. ${ }^{92}$

This ethics starts from the assumption that all individual persons have the same potential to determine and express their own sense of belonging and, therefore, their own distinctive identity. This sameness, the principle of equality of difference, must become an imperative in acknowledging and recognizing people's differences in their own original way of selfhood and its expression in social relations. The ethics of deep diversity, then, promises a discourse of emancipation from social marginalization and exclusion. ${ }^{93}$

Such an approach provides for a bottom-up notion to build a diverse and complex public space of commemoration rather than a state-imposed one. Public spaces can commemorate cultures from the perspectives of the cultures themselves without anyone being silenced or excluded.

The ethics of deep diversity ... appeals for a more rooted conception of polity embracing everyone without ascribing them any sense of being silenced or excluded. That is to say, the ethics of deep diversity broadens gates of participation and encourages open-ended dialogue among all different participants for articulation of the agreed upon and allencompassing discourse of social life. Hence, at the beginning it appeals to taking into account the ignored and glossed over distinctiveness, passes through a full denunciation of discrimination and downgrading of people as second-class citizens and ends at the full dialogue position with them in an equal manner. ${ }^{94}$

Hence, the notions of deep diversity, the politics of recognition and equal worth eradicate one-dimensional and shallow conceptions of public spaces. Rather, deep diversity calls upon different cultures to build a vital cultural identity and presence in the public sphere. This identity is a project that starts with diverse cultures themselves. It should commemorate those cultures and identities from their own perspectives and not a governmentally or colonially imposed perspective. This approach should open the public space widely for rigorous confrontation through dialogue that addresses and does not avoid the injustices of the past.

92 Masaeli, The Ethics of Deep Diversity - Part I.

93 Masaeli M. 2013. The Ethics of Deep Diversity - Part II. Online at: http:// livebettermagazine.com/article/the-ethics-of-deep-diversity-in-multiculturalsocieties-part-ii/

94 Masaeli, The Ethics of Deep Diversity - Part II. 


\section{CONCLUSION}

South Africa is no idyllic rainbow nation upon which the international world is waiting to succeed. There are nevertheless elements of it, persons who have incorporated this into their daily lives and are striving for it. Then there is the emancipated born-free generation, with only second-hand memories of apartheid. They did not experience apartheid first hand, but they do experience the legacy thereof, which resonates with what they have been told and what has been read in school and in their free time. Statues such as Rhodes and CR Swart reinforce the memory of the legacy and what they have been told. Consequently, the narrative reads as follows: get rid of the statue and then get rid of the memory of apartheid and also attempt to get rid of the legacy. But can one get rid of the legacy and the memories caused by it by eradicating it or neutralising the public sphere? When there is no statue and all names are those of freedom fighters, and there is still poverty and dire socio-economic situations - to which statue will we go to confront these situations?

Hence it is argued that the top-down approach taken by the state has not been transformative enough to give effect to the requirements of substantive equality, freedom and human dignity. The primary iconoclasm approach of mere removal of statues in the formation of national identity may pose an even greater threat to equality. Such removal may amount to censorship. Mere additions by the state will negate deep diversity. A form of secondary iconoclasm that adheres to notions of deep diversity, equal worth and the politics of recognition should be followed instead. Deep diversity acknowledges that there are layers of identity formation in a society and that a top-down imposed state identity does not sufficiently celebrate diversity. Hence, the equal worth inherent in diverse cultures require the state to allow all cultures to develop their own identity formation equally. This should be done from within the specific culture and from the perspective of the culture rather than a top-down approach by the state.

What must be rejected is the removal of one discriminating narrative by replacing it with a superficial state-imposed narrative. What is necessary is a constant dialogue of diversity where issues are debated and diverse cultural identities of South Africa are presented and celebrated from the bottom-up and from their own perspective (or their own narrative). As Charles Taylor theorises, deep diversity should be a discourse that lifts people and groups of people out of social marginalisation and exclusion. Such an approach ends when all persons are in full dialogue on an equal footing.

It is too early to state with any measure of certainty or even to anticipate which direction identity formation in South Africa will take. After the RMF campaign, the eruption of smouldering anger, and the fast-paced dialogue of black consciousness and anti-white privilege, South Africa awaits a restless period of expectation as to emerging forms of identity formation. 